Проф. др Драган Симеуновић

Универзитет у Београду

Факултет политичких наука

dragan.simeun@gmail.com

https://doi.org/10.18485/ai_filip_visnjic.2018.8 821.163.41.09-13:398 Вишњић Ф.

\title{
ПОЛИТИЧКО-ПРОПАГАНДНИ ДОПРИНОС ФИЛИПА ВИШЫИЋА ПРВОМ СРПСКОМ УСТАНКУ
}

„Пјесна добра спава у слијепца.“
Петар II Петровић Његош

У раду се анализира политички допринос Филипа Вишњића Првом српском устанку кроз његову поетску и пропагандну делатност. Филип Вишњић је поред тога заслужан за нашу историографију и етнографију јер је, иако слеп, са фактографском тачношћу бележио у својим песмама важне детаље ратних збивања, имена бројних учесника која би иначе потонула у заборав, па чак и начин облачења ратујућих са обе стране. Био је не само пропагатор револуционарних идеја, већ и њихов творац. Како је забележио Вук Караџић, већину важних Вишњићевих песама које се тичу догађаја у Првом српском устанку и догађањима везаним за устанак, спевао је он сам, и, што је важније, поенте и поруке тих песама, које су потом заживеле у народу као идеје и истине, биле су такође његово дело. Данас, 250 година након његовог рођења, након увида у његов живот и дело можемо констатовати да је био важан не само културни већ и политички чинилац подизања и успеха најважније српске револуције, а да тога ни он тада, ни други после, нису били довољно свесни.

Кључне речи: Филип Вишњић, усмена уметност, Први српски устанак, родољубље, усмена пропаганда, устанички дух, Вук Караџић. 
Неправда коју чинимо ствараоцима усмене уметности тиме што њихова дела, попут српске епске поезије, сврставамо у народне умотворине, опстаје и поред свих модернизација српског друштва. Као да је тек слово једини доказ нечијег ауторства и као да еманација духа није налазила хиљадама година своју потврду и без записа.

Филип Вишњић је свакако не само један од најзначајнијих уметника Првог српског устанка, већ и творац усмене, у стих уклесане, историје тих грандиозних збивања која су из корена мењала предуго тужну историју српског народа. Прецизност чињеница које са фактографском тачношћу Филип Вишњић уграђује у своје гусларске песме чини да су те песме аутентични и важни документи епохе.

Славни гуслар је према подацима које је о себи дао Лукијану Мушицком рођен 1767. године у босанском селу Трнова на размеђи равне Семберије и планине Мајевице, од оца Ђорђа и мајке Марије, од милоште зване Вишња. Пре него што је као дете ослепео од великих богиња нагледао се турског зулума у родној кући угледне породице Вилића. Када је због одбране девојачке части турски бес затро кућу Вилића, Филип је са мајком, младом удовицом по чијем надимку ће узети презиме, прешао у нови дом у другом селу. Запостављен од свих у својој новој породици, мали слепи дечак је рано дошао у додир са гуслама које ће променити његов горки живот. Као у бајци када млади јунак проналази чаробни мач, и даровити Филип је узевши у руке своје песничко оружје не само променио свој живот, већ и снажно утицао на животе и судбине многих других несрећних људи. За Србе није било песме без гусала. И то какве песме, пркосне и родољубиве која је већ својим тоном уз одсјај огњишта узбуркавала крв и 
свест српске раје. Није без прекора забележио турски хроничар тога доба да се „раја мање бунила ђе су гусле и пјесма Каурима брањени“. Захваљујући Вишњићу српски устаници нису били само „поколење за пјесну створено“, како је певао велики Његош, а врсно разумео Миро Вуксановић ${ }^{1}$, већ и поколење створено песмом и гуслама.

Поставши нешто посебно, свестан да је истина оно што он испева и отпева, путовао је неуморно од села до села, неустрашиво будећи замрло родољубље у наплашеним српским сељачким душама. Поновити Вишњићева путовања данас би и аутомобилом био велики напор, а може се замислити тек колика је била његова енергија и воља да споји Србе својом песмом и гуслама као њиховим јединим етничким медијем тога времена док је својим квргавим слепачким штапом пипао, корак по корак, хиљаде километара сеоским прашњавим и блатњавим путевима по мећавама и свакаком другом невремену у забаченим крајевима, праћен турском поругом, псима и каменицама махалске дечурлије.

Упоран да бакљу буне разноси где год има Срба, слепи Вишњић је прошао не само велик део Босне и Херцеговине, почев од Бијељине, Рогатице, Фоче, Горажда, Власенице, Зворника, Тузле, Маглаја, Бање Луке, Дервенте, Тешња, Жепче, Травника, све до околине Сарајева, Гацког и Грахова; већ и Црне Горе од Цетиња, Подгорице, Скадра, Шавника, Никшића, Жабљака до Пљеваља; као и Србије од Пријепоља до Лознице и Београда, па потом Смедерева, Ваљева, Крагујевца и Чачка. Многе од тих места, разуме се и бројних села међу

1 Види: Вуксановић, Миро. „Кључне речи Филипа Вишњића“. Филип Вишғић - међаш усмене и уметничке поезије. Нови Сад: Матица српска, 2011. Стр. 10. 
њима, походио је више пута, а стизао је не само у Срем, већ и у Бачку све до Кулпина, крстарио Славонијом од Винковаца до Нове Градишке и Осијека, па онда Панонијом ходио све до, тада у много чему српског, Темишвара.

Народ је тада очекивао свог „пјевача“ Вишњића са особитим узбуђењем. Данима је испред њега путовао глас да пева забрањене песме које су крепиле надолазећу храброст у временима буна и тако палиле искру замрле српске слободе. Тако је Филип Вишњић постао, попут многих других себи сличних, важан чинилац подизања и успеха револуције, а да тога ни он ни други нису били довољно свесни. Говорећи данашњим језиком он је не само био пропагатор револуционарних идеја, већ и њихов творац. Како је забележио Вук Караџић, већину важних Вишњићевих песама које се тичу догађаја у Првом српском устанку и догађањима везаним за устанак, спевао је он сам, и, што је важније, поенте и поруке тих песама, које су потом заживеле у народу као идеја и истина, биле су такође његово дело. Отуд он није само весник, већ и „доносилац идеје преврата“" , идеје прве револуције једног од заробљених народа у најстрашнијем од свих непоредака тога времена.

Српски Хомер ${ }^{3}$, како с правом можемо звати Филипа Вишњића, био је уједно и дух и језик српске рево-

2 Винавер, Станислав. „Покушај ритмичког проучавања мушког десетерца“. Павле Зорић (прир.). Критички радови Станислава Винавера. Нови Сад, Београд, 1975. Стр. 306.

3 За разлику од Јернеја Копитара који је већ упрвом приказу Вукове Пјесмарице из 1815. означио Филипа Вишњића као „српског Хомера“, Станислав Винавер сматра да Филип Вишњић много више „инстинктом великог песника уподобљава себе Есхилу“. Винавер, Станислав. „Трагично надахнуће Филипа Вишњића“. Павле Зорић (прир.). Критички радови Станислава Винавера. Нови Сад, Београд, 1975. Стр. 250. 
луције. Свестан своје одговорности служио се у својим песмама што је више могао истином, свестан да је она најбоље оружје за подстицање на велика дела. Одувек су велики пропагатори идеја и револуција знали да семе истине рађа највеће борбене митове који, такви какви су, архајски саздани од маште и наде, тек у споју са истином постају друштвено функционални и моћна покретачка снага народних маса.

Његова пропагандна мисија била је лична. Нико то од њега није захтевао, нити га је ко из руководства устанка финансирао. Издржавао се милостињом и прошњом (да ли је то била злосутна феноменолошка најава општег положаја културних прегалаца у Срба?). Однос према Вишњићу показује и то да Срби очито ни тада нису схватали значај лобирања и пропаганде, нити су ишта улагали у њих зарад остварења својих политичких циљева. Ретки су били они који су попут Стојана, војводе мачванског, разумели велики значај Филипа Вишњића као агитатора по успех целог устанка.

Вишњић је и сам био учесник великих збивања, рецимо у војној опсади побуњене Лознице 1810. када је једва преживео турски масакр малобројних бранилаца које је својом песмом бодрио недељама и пре и после доласка Карађорђа и његове војске.

Вук Караџић није записао ниједну Вишњићеву песму која је настала пре устанка, па стоји претпоставка да он можда пре „востанија србског није једну песму сам сочинио“, како уосталом, пре тачно сто година, бележи након разговора са њим 1817. године у сремачком манастиру Шишатовац и Лукијан Мушицки. Логично je, додуше, да је Филип Вишњић као сваки песник имао своје песме и пре тог за Србе највећег историјског догађања од великих сеоба. Но, за претпоставити је и то да оне нису биле од велике вредности по револуцију, 
нити да је он пре њеног почетка могао имати тако великог надахнућа какво су у њему пробудили узбудљиво устаничко доба и конкретни догађаји у њему. Тек када је устанак избио, Вишњићево родољубље је преобличило Вишњића од интерпретатора у креатора песама, а тиме и у истинског гласника буне. Инспирације је било и одвише тих година посвуда око њега, јер је Вишњић живео животом гуслара и песника рата, а не салонских романтичара који су уздисали над славном прошлошћу. Док су други гуслари и даље гуслали старе песме, нове је стварао само Вишњић. Ако није био у свакој важнијој бици, након ње је скупљао подробне податке о учесницима и току битке, чак и о томе како су били обучени и српски и турски актери крвавих бојева и какви су им били коњи. Зачудна је сликовитост његових описа неба замраченог од барутног дима, звукова који прате судар двеју војски, као и уверљивост приказа непрепознавања „својих“ у бици, који стварају богату фантасмагоричну представу онога што се збило и онога што је својим духовним очима видео Филип Вишњић.

Данас то представља изванредан, ретко веродостојан историјски извор за реконструкцију тих догађаја. О томе је својевремено, али без довољне резонанце, писао и велики Слободан Јовановић упоређујући Вуков историографски текст „Прве године војевања на дахије“ и Вишњићев спев „Бој на Чокешини“4. Само оно што је од Вишњићевог дела забележио Вук Караџић износи преко 5.000 стихова. Они су, заједно узев, понајвише слика његове епохе, чак и онда када у њима он пева о старим јунаштвима и јунацима јер су и те песме биле у функцији подизања и одржања устаничког духа у његовом простору и времену.

4 Види: Јовановић, Слободан. „Филип Вишњић“. Из наше историје и книжевности. Београд, 1931. 
Међутим, сводити његове песме тек на пропагандни материјал, макар и изванредан, била би велика грешка. Те песме су уједно изврсна, добро осмишљена аналитичка грађа у којој се прецизно утврђују узроци устанка, друштвене и политичке околности у којима се он збива, начин вођења ослободилачке борбе, разлози губљења даха револуције и најзад њеног привременог краха.

Радикалност револуције као чина потпуног преврата је код Вишњића препозната и утврђена већ у почетним стиховима његове знамените песме „Почетак буне против дахија“: „Кад се шћаше по земљи Србији, по Србији земљи да преврне и да друга постане судија...”.

Мотиви за устанак су Вишњићевим гудалом пажљиво сабирани и одабрани тако да се зачињу поменом Маричке и Косовске битке, након чега следе редом осуде примера вековног турског насиља и значајних неправди учињених српском народу и цркви, да би на крају били заокружени сечом српских кнезова која је била најважнији актуелни повод за дотад највећу српску буну против турске власти и зулума. Мало је мислилаца у нас који су попут Љубомира Симовића уочили суптилне мене мотивацијских упоришта ${ }^{5}$ код ликова које опева Вишњић.

Узроци за побуну се код Вишњића препознају као дубљи и дају се свести на три речи: воља за слободу. Слободу од зулума, харача, ропства сваколика, слободу која се не поклања већ се до ње стиже само „борбом непрестаном“, дакле „јуначку слободу“. Нико боље од Вишњића који је прокрстарио друмове српских крајева није могао одвојити генералне од посебних узрока за тако велику народну побуну, нити тако тачно знати

5 Види: Симовић, Љубомир. „Песме Филипа Вишњића“. Дупло дно. Београд, 2001. 
шта то тишти српску рају. Њега као и његов народ не интересује више правде као мање неправде у ропству, већ слобода као највиша правда.

Исто тако запањује Вишњићев реализам који чак и у тренуцима највећег устаничког заноса Дрину и даље види као границу између Босне и Србије - „Дрино водо, племенита међо измеђ Босне и измеђ Србије“", границу која се може и мора прелазити и ради рата и ради мира, али као и све велике водене препреке остаје границом док је „мнози мости“ не обесмисле. На какве је све мостове преко Дрине Вишњић при том мислио не да се тачно утврдити из сачуваних материјала, али се из помињања исте вере и исте традиције, а понајвише исте судбине народа с обе стране Дрине, понешто да претпоставити. Може се рећи и то да је творећи и сам историју, Филип Вишњић очито много ослањао на свеукупну познату му историју српског народа из чега је исткао слутњу да је судбина српског народа да дуго, а можда и заувек живи у подвојеним државама.

На основу анализе Вишњићевих стихова да се закључити да је поседовао ону способност предвиђања, која се назива прозорљивошћу. Она је била толика да се Станислав Винавер зачудио Вишњићевим „интуицијама и прозрењима“". Тако, он у истој песми наговештава скори пренос устанка у Босну, али не и победу Срба, као ни евентуално спајање Босне и Србије, ма колико да му је то била жеља, када каже певајући у Карађорђево име „Наскоро ће и то време доћи“када ће прећи са војском Дрину и „честиту Босну полазити“. И одиста, Срби у Семберији под вођством кнеза Иве од Семберије, Вишњићевог доброг пријатеља, подигоше заједно

6 Вук Караџић, Српске народне пјесме, Београд, 1958.

7 Винавер, С, исто, стр. 251. 
са Карађорђевим борцима 1809. устанак против Турака, који се завршио сломом, између осталог и због данас мало познате чињенице да је подршку Турцима против српских устаника у Босни пружила француска артиљерија. У том устанку је учествовао и Филип Вишњић и по његовом слому се заједно са великим збегом народа из Семберије прво настанио у Мачви, а потом трајно у Срему.

Осим тога, многи ликови не само главних, већ и маргиналних јунака тога простора и доба су остали да живе у нашем памћењу само захваљујући Вишњићевом дару за меморисање личности и збивања, као и његовом осећању за правду које се исказивало и у немалом давању простора у његовим песмама мање битним ликовима устанка, неретко простим борцима који су учинили по које велико дело које би иначе било приписано њиховим старешинама. Није ли и то дизало морал народу и чинило сам народ јунаком достојним својих вођа? Вишњић је, уз то, мудро резоновао да је погрешно опевати само своје вође. Зато је у својим песмама детаљно опевао и турске зликовце свих формата. Да би их упознао, није се либио да их лично походи и да исте песме истим тоном пева и њима, као што их је певао и пред српским вождом. Храброст слепца је понекад већа од храбрости оних који виде, али не зато што је у питању компензација већ зато што његова храброст проистиче из другачије формираног карактера, другачијег схватања вредности живота и у овом случају из рано изграђеног Вишњићевог смисла жртвовања за народ. Услед свега тога његова храброст је само бивала већа од очекиване. Из ратних похода, а још више из посета Турцима Филип Вишњић се понекад враћао без прстију и са бразготинама по лицу када би Турци спознали да жели да их упозна само зато да би их касније могао што боље опевати мртве. 
Пошто су се српски устаници мало служили пером, велика је заслуга Филипа Вишњића што је живо и занимљиво меморисао догађаје, стекавши тиме право на титулу једног од наших најзначајнијих прегалаца нововековне културе усмености ${ }^{8}$, једнако као што је огромна и заслуга Вука Караџића зато што је записао Вишњићеве стихове препознавши у њима велику литерарну и историјску вредност. Оцењено као европски вредно 9 , Вуково дело је у одређеној мери уједно и духовна оставштина Филипа Вишњића. Примера ради, Димитрије Стефановић наводи имена двадесет и једног страног композитора који су створили дела инспирисана Вуковом збирком српских народних песама, међу којима су и таква имена као што су Брамс, Дворжак и Чајковски.

Снага израза у Вишњићевим песмама је увек у сплету са идејом. Она није посвећена јунаштву како би се дало помислити кад је реч о песмама које су спеване у устанку и за устанак, па чак ни чојству, већ уздизању до апсолутног моралног стања („Своју душу врћи у чистоту“), као врховној људској светости до које на путу самообожења треба да иде појединац који таквом подвигу стреми.

Но, у тим стиховима поред похвала јунаштву и племенитости ретког кова каква је била она кнеза Иве од Семберије, има и подоста критике на рачун кукавичлука и грешака српских главешина. Задуго још нико сем Филипа Вишњића неће тако слободно изрицати

8 О култури усмености види: Славко Гордић, „Филип Вишњић из века у век“, Филип Вишғић - међаш усмене и уметничке поезије, Матица српска, Нови Сад, 2011, стр. 19.

9 Види: Димитрије Стефановић, „Осврт на Вуково наслеђе у Европској музици“, Вук Стефановић Караиић (1787-18642014), Научни скупови Српске академије наука и уметности, књ. CLVI, Одељење језика и књижевности, књ. 27, стр. 581. 
бритке осуде штетног понашања лидера српске револуције 1804. године, које он најчешће прати речима „Шта чините, да вас Бог убије?“.

Један од разлога за толику Вишњићеву слободу речи је садржан и у патријархалној демократичности која је красила Први српски устанак. Милорад Панић Суреп тачно примећује у својој студији о Вишњићу да се тако о Милошу у Другом устанку не би смело певати.

Филип Вишњић је, и поред своје скромности која га је красила попут средњевековног ствараоца ${ }^{10}$, имао у име своје песничке слободе и своје право на разочарење. Иако се након пропасти устанка скућио у Срему међу поштоваоцима његове песме на Фрушкој Гори у селу Грк, горак због краха устанка одбијао је да мирно живи мада је по први пут био „ситуиран“ (добио је од сељана таљиге и коња да се издржава) и најзад био заједно са својом децом, те је, и поред тога, пуних следећих двадесет година, од 1813. па све до 1834. наставио са својим путовањима. Површном посматрачу би се могло учинити да је реч о лутањима, а заправо се радило о наставку гусларевог сна, о поновном његовом уделу у повезивању костију и ткива разбијеног српског националног тела помоћу гусларско-друмских нити ради уздизања посрнуле српске револуције.

Када је у 67. години живота умро и сахрањен у свом сремском селу (данашње Вишњићево), Филип Вишњић је био легенда, али само у народу. Нови владари Срба нису много марили за њега. Срмом оковане велике гусле Вишњићеве су иструлиле заденуте за рог старе куће, а гудало које је мамило уздахе и жарило крв је продато за пар форинти.

10 Види: Растко Петровић, „Велико јутро над грмом Вишњићевим“, Путописи, Дела Растка Петровића, књ. V, Београд, 1977, стр. 56. 
Филип Вишњић је умро у времену када за њега више није било посла. Његова смрт се такорећи поклапа са укидањем последњих феудалних обавеза у Србији, на Ђурђевдан 1835, што се сматра чином који означава крај Српске револуције ${ }^{11}$. Његов крај и крај једне од најузбудљивијих европских националних епопеја Новога века, дошли су, не случајно, заједно. Бајковити задатак слепог дечака из Подриња који је он сам себи зарана поставио био је доведен до краја. Србија је била довољно слободна, а Срби и живи и мртви једни до других. Када је замукла његова песма остао је само његов завет Србима да не дозволе да се ни мртви више растављају - „Нека је кост до кости, децо!“. Потом помреше после Вишњића брзо и изненадно и сва његова деца. Сељани Грка их сходно Вишњићевом завету сахранише тик поред њега. Његове песме и идеје су остале да живе као заветно штиво у читанкама. Да ли и у главама политички мислећих?

\section{Литература:}

Винавер, Станислав. „Покушај ритмичког проучавања мушког десетерца“. Павле Зорић (прир.). Критички радови Станислава Винавера. Нови Сад - Београд, 1975.

Винавер, Станислав. „Трагично надахнуће Филипа Вишњића“. Павле Зорић (прир.). Критички радови Станислава Винавера. Нови Сад - Београд, 1975.

Вуксановић, Миро. „Кључне речи Филипа Вишњића“. Филип Вишғић - међаш усмене и уметничке поезије. Нови Сад: Матица српска, 2011.

11 Назив „српска револуција“ први је употребио Леополд Ранке (Die serbische Revolution, Aus serbischen Papiren und Mittheilungen, von Leopold Ranke, Hamburg, 1829), а можда најбољу анализу те револуције, тако је уједно и називавши, дао је Светозар Марковић, у свом делу Србија на Истоку. 
Гордић, Славко. „Филип Вишњић из века у век“. Филип Вишьић - међаш усмене и уметничке поезије. Нови Сад: Матица српска, 2011.

Јовановић, Слободан. „Филип Вишњић“. Из наме историје и книжевности. Београд, 1931.

Караџић, Вук. Сриске народне пјесме. Београд, 1958.

Петровић, Растко. „Велико јутро над грмом Вишњићевим“. Путописи, Дела Растка Петровића, књ. V. Београд, 1977.

Ranke, Leopold. Die serbische Revolution, Aus serbischen Papiren und Mittheilungen. Hamburg, 1829.

Симовић, Љубомир. „Песме Филипа Вишњића“. Дупло дно. Београд, 2001.

Стефановић, Димитрије. „Осврт на Вуково наслеће у Европској музици“. Вук Стебановић Карачић (1787-18642014), Научни скупови Српске академије наука и уметности, књ. CLVI. Одељење језика и књижевности, књ. 27.

\section{Dragan Simeunović}

\section{ESSAY ON SERBIAN HOMER}

(On the occasion of $250^{\text {th }}$ anniversary of Filip Višnjićs birth)

\section{Summary}

This paper analyzes Filip Višnjićs contribution to the First Serbian Uprising through his poetic and propaganda work. Apart from this, Filip Višnjić is to be credited for contributions to our historiography and ethnography, since he, although blind, factually and accurately recorded, in his poems, important details of war events, names of numerous participants who would otherwise be forgotten, even the attire of warriors from both sides. He was not only propagator of revolutionary ideas, but also their creator. As recorded by Vuk Karadžić, most of Višnjićs important songs about events of the First Serbian Uprising or related to it, were composed by Višnjić himself. Even more importantly, points 
and messages of these songs, which later lived among the people as ideas and truths, were also his creation. Today, 250 years after his birth, we can, after the insight in his life and work, conclude that he was an important factor of inciting and success of the most important Serbian revolution, even though neither he at the moment nor others in later times were sufficiently aware of that.

Key words: Filip Višnjić, oral art, First Serbian Uprising, patriotism, oral propaganda, spirit of the uprising, Vuk Karadžić. 